\title{
Role of Trichodesmium spp. in the productivity of the subtropical North Pacific Ocean
}

\author{
Ricardo M. Letelier ${ }^{1, *}$, David M. Karl ${ }^{2}$ \\ ${ }^{1}$ College of Oceanic and Atmospheric Sciences, Oregon State University, Corvallis, Oregon 97331-5503, USA \\ ${ }^{2}$ School of Ocean and Earth Science and Technology, University of Hawaii, Honolulu, Hawaii 96822, USA
}

\begin{abstract}
The concentrations of filamentous diazotroph Trichodesmium spp., present as free trichomes and in colonial assemblages, were measured at approximately monthly intervals at Stn ALOHA $\left(22^{\circ} 45^{\prime} \mathrm{N}, 158^{\circ} 00^{\prime} \mathrm{W}\right)$ between October 1989 and December 1992 . The average abundance of filaments in the upper $45 \mathrm{~m}$ of the water column was highly variable ranging from 1.1 to $7.4 \times 10^{4}$ trichomes $\mathrm{m}^{-3}$ and from 0.02 to $1.4 \times 10^{2}$ colonies $\mathrm{m}^{-3}$. Colonies were composed, on average, of 182 filaments accounting for $12 \%$ of total (free filament plus colonies) Trichodesmium biomass. Low densities of single tnchomes were associated with, but not restricted to, deep mixing events and winter periods. During 1991 and 1992 the concentration of Trichodesmium spp. present in the water column increased relative to the pre 1991 observations. This increase coincided with increases in photosynthetic carbon assimilation and in the molar ratio of $\mathrm{N} P$ of suspended particulate matter in the upper $45 \mathrm{~m}$ of the water column. However, the change in Trichodesmium biomass alone does not account for the change observed in autotrophic carbon assimilation and elemental biomass composition. Trichodesmium spp. comprised, on average, $18 \%$ of the chlorophyll $a, 4 \%$ of the photosynthetic carbon assimilation, $10 \%$ of the particulate nitrogen and $5 \%$ of the particulate phosphorus. We also estimate that Trichodesmitum dinitrogen fixation accounted for, on average, at least $27 \%$ of the new production at this study site. These observations, combined with primary production experiments conducted on isolated colonies, suggest that phytoplankton production is enhanced due to the release of $\mathrm{NH}_{4}{ }^{+}$and dissolved organic nitrogen by Trichodesmium spp. during episodes of nitrogen fixation.
\end{abstract}

KEY WORDS: Trichodesmium · Nitrogen fixation · Nutrients - Productivity - Time-series

\section{INTRODUCTION}

Spatial and temporal distributions of the diazotrophic (nitrogen-fixing) cyanobacterium Trichodesmium have been extensively studied in the eastern section of the tropical North Atlantic Ocean and Caribbean Sea (Carpenter \& Price 1976, Carpenter \& Romans 1991\}, in the Indian Ocean (Devassy et al. 1978), in the East China Sea (Marumo \& Asaoka 1974a), and in the Pacific Ocean (Marumo \& Asaoka 1974b, Marumo \& Nagasawa 1976). The presence of Trichodesmium has also been frequently reported in oligotrophic marine environments in the context of phytoplankton bloom phenomena (Bowman \& Lancaster 1965, Dupuoy et al. 1988, Karl et al. 1992). Nevertheless, the importance of

·E-mail; letelier@oce.orst.edu
Trichodesmium in marine ecosystems and the marine nitrogen cycle remains a matter of debate (Carpenter 1983, Codispoti 1989, Capone et al. 1992).

Field observations have shown that Trichodesmium colonies become abundant in surface waters of tropical and subtropical marine ecosystems during periods of calm weather (Steven \& Glombitza 1972, Carpenter \& Price 1976, Bryceson \& Fay 1981, Karl et al. 1992). These colonies of Trichodesmium cells support an entire localized ecosystem including epiphytic heterotrophic bacteria (Carpenter \& Price 1976, Borstad \& Borstad 1977, Paerl et al. 1989), diatoms (Borstad \& Borstad 1977, Bryceson \& Fay 1981), and hydrozoans (Geiselman 1977, Borstad \& Brinckmann-Voss 1979). There is also evidence that the survival rate of larval stages of the copepod Macrosetella gracilis (Dana) increases when Trichodesmium is present (Bjornberg 1965, Calef \& Grice 1966, Roman 1978). Trichodesmium 
also undergoes rapid lysis when senescent (Van Baalen \& Brown 1969, Borstad \& Borstad 1984). Devassy et al. (1979) concluded from the succession following a Trichodesmium bloom that rapid cell structure degradation resulted in an increase of inorganic nutrients in the water column, presumably the result of a rapid and efficient microbial recycling of organic constituents following cell lysis. Furthermore, recent studies indicate that, even under healthy conditions, Trichodesmium releases $\mathrm{NH}_{4}^{+}$(Prufert-Bebout et al. 1993) and dissolved organic nitrogen (Capone et al. 1994, Glibert \& Bronk 1994) during the process of nitrogen fixation. These observations suggest that fluctuations in the abundance of Trichodesmium in the pelagic marine environment may affect both the taxonomic and chemical composition of the ambient plankton community. In the subtropical North Pacific gyre, where nitrogen is generally considered to be the production rate limiting nutrient controlling productivity, nitrogen fixation and its release in the form of ammonium, or other utilizable forms of nitrogen, may be an important source of 'new' nutrient for phytoplankton otherwise incapable of direct assimilation of gaseous nitrogen.

Most field studies of Trichodesmium have concentrated on either the spherical or fusiform colony morphologies of this genus in spite of the fact that Marumo \& Asaoka (1974a) and Marumo \& Nagasawa (1976) have reported that a major fraction of Trichodesmium biomass occurs in the form of single trichomes. Historically, single trichome morphology has been considered less important in the context the marine nitrogen cycle because it was thought that nitrogen fixation occurred only in sub-oxic microenvironments found in the center of selected colonies (Carpenter \& Price 1976, Bryceson \& Fay 1981, Paerl \& Bland 1982, Paerl \& Prufert 1987, Paerl \& Bebout 1988, but see Saino \& Hattori 1982). This view has recently been challenged as a result of studies of nitrogen fixation performed in Trichodesmium cultures (Ohki \& Fujita 1988, PrufertBebout et al. 1993) and by enzymatic analyses of natural Trichodesmium assemblages (Capone et al. 1990, Carpenter et al. 1990, Bergman \& Carpenter 1991). This evolution of thinking about the potential role of free trichomes in nutrient cycles has prompted renewed speculation about the quantitative importance of oceanic nitrogen fixation processes.

The Hawaiian Ocean Time-series (HOT) program is designed to characterize oligotrophic habitat and ecosystem variability in the water column at Stn ALOHA (A Long-term Oligotrophic Habitat Assessment, $22^{\circ} 45^{\prime} \mathrm{N}, 158^{\circ} 00^{\prime} \mathrm{W}$ ). This program provides an optimum background data set to study the effects that changes in Trichodesmium abundances may have in the biochemical characteristics of the euphotic zone. In this paper we report results of the study of the distri- bution of Trichodesmium in the euphotic zone of Stn ALOHA between August 1989 and December 1992. We also analyze the variability of Trichodesmium biomass in the upper $45 \mathrm{~m}$ of the euphotic zone as it relates to changes in the elemental ratio of particulate matter and primary production over similar depth ranges.

\section{METHODS}

The Hawaiian Ocean. Time-series (HOT) program investigators sample the water column of Stn ALOHA at approximately monthly intervals as part of the United States-Joint Global Ocean Flux Study (USJGOFS; Karl \& Winn 1991, Karl \& Lukas in press). As part of this program, water column suspended particulate carbon (PC), particulate nitrogen $(\mathrm{PN})$, particulate phosphorus (PP), and pigments wete measured during each cruise. Water samples (4 to $10 \mathrm{l}$ ), collected with a 24.-position rosette water sampler equipped with 12 I polyvinylchloride (PVC) bottles and SeaBird CTD, wete pre-scieenced through a $202 \mathrm{\mu m}$ mesh and filtered onto combusted $25 \mathrm{~mm} \mathrm{GF/F} \mathrm{Whatman} \mathrm{filters} \mathrm{for} \mathrm{PC}$ and PN analyses, or onto combusted and acid washed $25 \mathrm{~mm}$ GF/F filters for PP analyses. PC and PN were measured simultaneously in a Perkin-Elmer model 2400 CHN analyzer. PP was quantified spectrophotometrically. For this analysis samples were combusted $\left(450\right.$ to $500^{\circ} \mathrm{C}$ ), acidified $\left(0.5 \mathrm{~N} \mathrm{HCl}\right.$ at $90^{\circ} \mathrm{C}$ for $90 \mathrm{~min}$ ) and color proportional to the concentration of phosphorus in solution was developed by adding a mixed reagent freshly prepared $(10 \mathrm{ml}$ ammonium molyb-

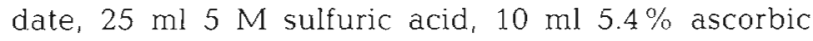
acid and $5 \mathrm{ml}$ potassium antimony tartrate; Strickland \& Parsons 1972) Particulate samples for pigment analyses were collected and quantified using the chromatographic method described by Letelier et al. (1993).

In order to assess the temporal and vertical distributions of Trichodesmium colonies, horizontal net tows of discrete subsurface layers were obtained using an opening-closing plankton net (Omori 1965; $50 \mathrm{~cm}$ in mouth diameter, $270 \mathrm{~cm}$ in filtering cloth length and $100 \mu \mathrm{m}$ in mesh size, $9 \mathrm{~cm}$ bucket diameter with $60 \mu \mathrm{m}$ mesh size) between March 1990 and October 1991. When not counted at sea, samples were preserved in $5 \%$ buffered formalin and analyzed at our shore-based laboratories. A flow meter (General Oceanics) was mounted at the mouth of the net to calculate the total volume of water filtered during each tow and convert colony numbers to densities. A typical horizontal tow sampled approximately $4.3 \mathrm{~m}^{3} \mathrm{~min}^{-1}$ and lasted $10 \mathrm{~min}$. Vertical net tows ( 0 to $100 \mathrm{~m}^{1} 16 \mathrm{~m}^{3}$ total) were also performed between May 1990 and October 1991 to com- 
pute an independent estimate of the depth-integrated concentration of colonies

To assess the elemental (PC, PN, PP) and pigment compositions of Trichodesmium at Stn ALOHA, colonies from net tow samples were isolated using a Pasteur pipette, rinsed and vortexed in $50 \mathrm{ml}$ filtered seawater to produce a suspension of single trichomes. Subsamples were transferred onto combusted $\mathrm{GF} / \mathrm{F}$ filters, as above. Triplicate samples (>10 colonies per filter) were analyzed for each determination.

To examine the natural distribution of single trichomes, seawater was collected at discrete depths using the rosette water sampler described above. Water samples (4 to $10 \mathrm{l}$ from each depth) were gently filtered onto Nitex mesh (10 $\mu \mathrm{m}$ mesh size). The mesh was back rinsed with $50 \mathrm{ml}$ filtered seawater to resuspend the trichomes after manual removal of colonies, if present. This suspension was then filtered onto $0.8 \mu \mathrm{m}$ $25 \mathrm{~mm}$ Nuclepore filters prestained with irgalan black and mounted on microscope slides. Trichomes were enumerated by epifluorescence microscopy based on phycoerythrin autofluorescence. To avoid overestimating the quantity of single trichomes in a sample as a result of filament breakage during processing, only apical cells were enumerated rather than total trichomes (intact filaments have shaped apical cells at either end). The abundance of single trichomes reported here corresponds to the number of apical cells divided by 2

The elemental (PC, PN, PP) composition of single trichomes was studied on 2 separate occasions. A total of 8 replicates of $10 \mathrm{l}$ each collected at $45 \mathrm{~m}$ depth were screened onto $10 \mu \mathrm{m}$ mesh as described above. All replicates were combined into a single $500 \mathrm{ml}$ pooled sample from which five $100 \mathrm{ml}$ aliquots were drawn. One of the samples was used for microscopic enumeration, 1 for PP, 1 for pigment and 2 for PC/PN.

The abundance of trichomes found in colonial morphology was compared to the abundance of single trichomes by counting the number of filaments per colony. Triplicate $60 \mathrm{ml}$ samples of filtered seawater containing 20 to 30 hand-picked colonies per sample were vortexed until no visible colonies remained in the suspension ( 5 to $30 \mathrm{~min}$ ). From each sample, triplicate $5 \mathrm{ml}$ subsamples were withdrawn and filaments were enumerated as described above.

During March 1990 and August 1991, primary productivity experiments were performed in conjunction with the standard primary productivity incubations of the HOT program to assess the contribution of Trichodesmium colonies to photoautotrophic production at Stn ALOHA. Colonies were collected at night from 5 , 25, 45 and $75 \mathrm{~m}$ and transferred into filtered seawater corresponding to the respective sampling depth. All colonies were observed under a stereoscopic micro- scope to select only those that appeared to be intact and free of copepods. Once the regular primary production experiment had been deployed (see Letelier et al in press), the remaining water was used to fill triplicate $500 \mathrm{ml}$ polycarbonate incubation bottles for each water depth. One Trichodesmium colony was added to each bottle. This amounted to an increase in chlorophyll a (chl a) of approximately $100 \%$. Triplicate polycarbonate bottles containing filtered $0.2 \mu \mathrm{m}$ sterile filtered seawater were also inoculated with 3 colonies each. $\mathrm{NaH}^{14} \mathrm{CO}_{3}$ (final activity $=0.1 \mu \mathrm{Ci} \mathrm{ml} \mathrm{m}^{-1}$ ) was used as radiotracer to measure carbon assimilation. The samples were incubated on deck from approximately dawn to dusk under in situ simulated light and temperature conditions.

To correlate Trichodesmium abundances measured during each cruise with antecedent weather conditions, the sea surface temperatures (SST) recorded at hourly intervals by the National Data Buoy Center (NDBC) buoy no. $51001\left(23^{\circ} 24^{\prime} \mathrm{N}, 162^{\circ} 18^{\prime} \mathrm{W}\right)$ were analyzed. From these hourly averages, we calculated a relative stability index based on the amplitude of the diel SST cycle. This approach assumes that the diel SST warming cycle, due to the local heating and cooling of the sea surface, increases in amplitude under calm weather conditions as a direct result of a decrease in turbulent mixing. Hence, a large daily amplitude in the diel SST cycle indicates stratification of the upper water column, while a low amplitude indicates a wellmixed water column (Karl et al. 1995).

\section{RESULTS}

The estimated densities of Trichodesmium colonies and single trichomes at Stn ALOHA are highly variable (Fig. 1). The concentration of single trichomes averaged over the upper $45 \mathrm{~m}$ of the water column ranges from 1.1 to $8.4 \times 10^{4}$ filaments $\mathrm{m}^{-3}(\bar{x}=4.6 \times$ $10^{4}$ filaments $\mathrm{m}^{-3}, \mathrm{~s}=2.3 \times 10^{4}$ filaments $\mathrm{m}^{-3}, \mathrm{n}=22$; Fig. 2B). Colony densities averaged over the same depth intervals ranged between 2 and 140 colonies $\mathrm{m}^{-3}$ $\left(\bar{x}=31\right.$ colonies $\mathrm{m}^{-3}, \mathrm{~s}=41$ colonies $\mathrm{m}^{-3}, \mathrm{n}=11$; Fig. $\left.2 \mathrm{~B}\right)$. Colony size also varied considerably in single samples (<10 to 372 filaments colony ${ }^{-1}$ ). Nevertheless, the mean size between cruises varied only $85 \%$ (132 to 241 filaments colony ${ }^{-1}, \bar{x}=182$ filaments colony ${ }^{-1}, \mathrm{~s}=23$ filaments colony ${ }^{-1}, n=11$ ).

Although the size of filaments covered a large range ( 6 to $>250$ cells trichome $\mathrm{e}^{-1}$ ), the average size for both morphologies (single trichomes and colonies) was similar (approximately 100 cells trichome ${ }^{-1}$ ). Trichodesmium cells in colony morphology, therefore, comprised $12 \%$ ( $\mathrm{s}=11 \%, \mathrm{n}=11$ ) of the total Trichodesmium biomass. 

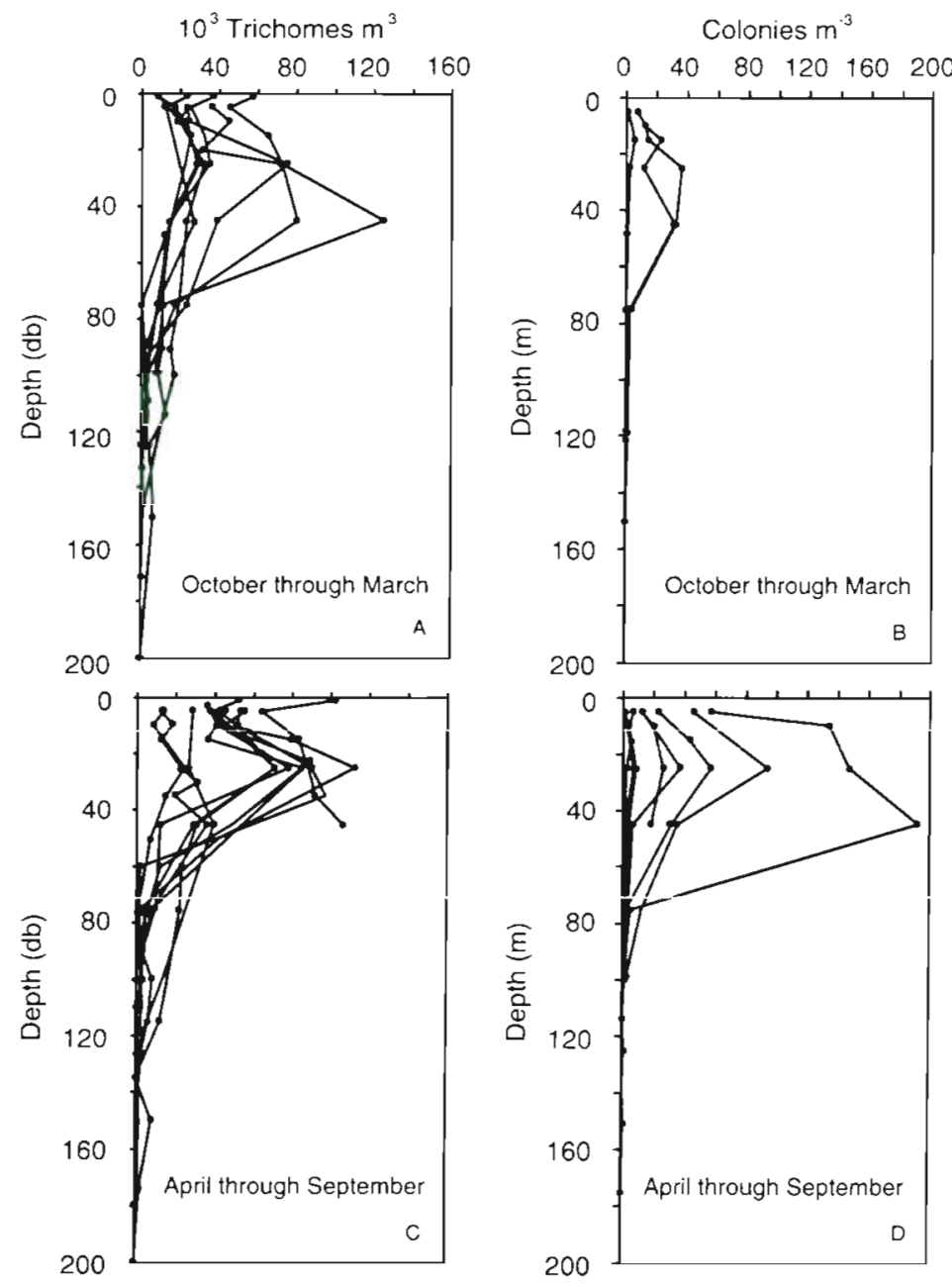

Fig. 1. Trichodesmium spp. Vertical distribution of single trichomes $(A, C)$ and colonies (B, D) at Stn ALOHA between October 1989 and December 1992
The slope of a linear regression (model If geometric mean) between integrated colony concentration calculated from 0 to $100 \mathrm{~m}$ vertical net tows and from samples collected at discrete depths (horizontal net tows) was not different from $1.0(95 \%$ confidence limits $=0.84$ and 1.06, $\mathrm{R}^{2}=0.85, \mathrm{n}=9$; Fig. 3) indicating that our sampling procedures were accurate. This result suggests that the reconstruction of the depth distribution of colonies from discrete depth samples is a valid representation of the vertical structure of the colony distribution for the water column.

The vertical distribution of both the filament and colony morphologies displays a subsurface maximum located between 20 and $50 \mathrm{~m}$ in all cruises where the mixed-layer depth is <50 m (Fig. 1). However, this subsurface maximum disappears when the mixed-layer deepens and exceeds a depth of $50 \mathrm{~m}$. A near surface maximum of single trichomes ( 2 to $5 \mathrm{~m}$ ) is also observed in $40 \%$ of the cruises and, although an accumulation of colonies at the sea surface was visually observed from the ship on 2 occasions (August 1991 and June 1992), this feature was not visible at the time of sampling and was not resolved by the sampling procedures employed

The abundance of single trichomes in the first $45 \mathrm{~m}$ of the water column does not correlate with the average diel SST amplitude calculated from the NDBC buoy no. 51001 . Several running averages, from 1 to $14 \mathrm{~d}$ intervals, were performed to assess the cor-

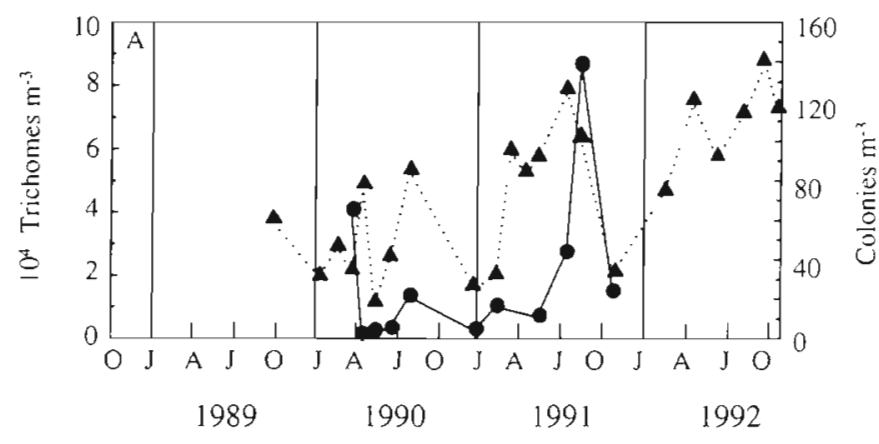

Fig. 2. Trichodesmium spp. Temporal variation of (A) diel amplitude of sea surface temperature (SST) measured at $23^{\circ} 24^{\prime} \mathrm{N}, 163^{\circ} 18^{\prime} \mathrm{W}$ (see 'Methods') and (B) average densitues of single trichomes ( $\triangle$ ) and colonies ( $\bullet$ in the upper $45 \mathrm{~m}$ of the water column at Stm ALOHA. O: October; J January or July; A: April

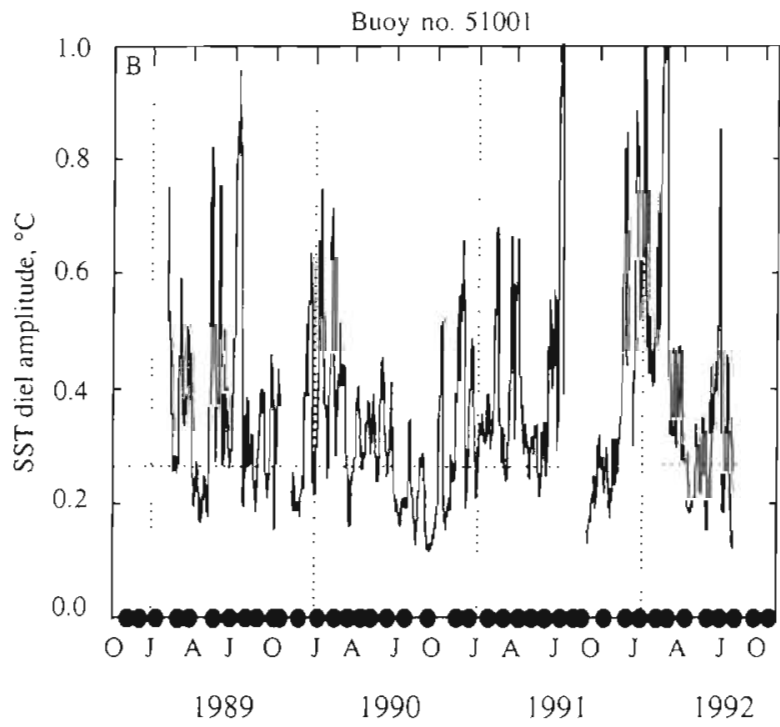




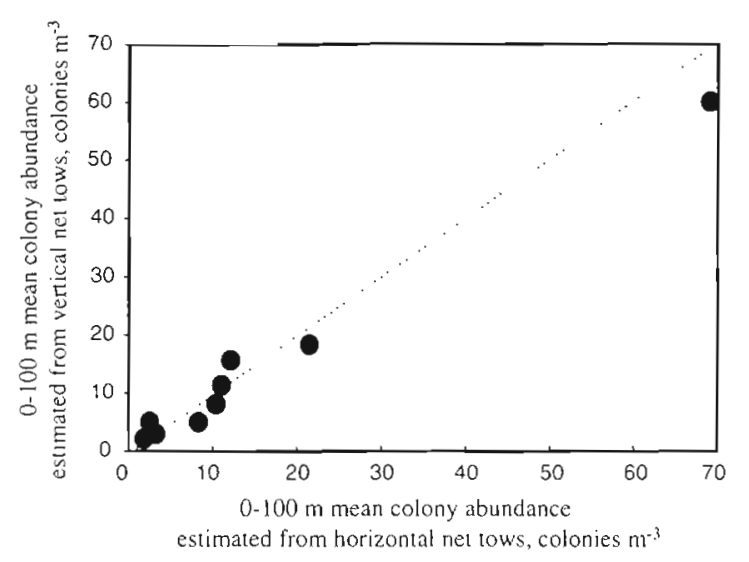

Fig. 3. Trichodesmium spp. Comparison between the mean abundance colonies over the upper $100 \mathrm{~m}$ of the water column estimated from 0 to $100 \mathrm{~m}$ vertical net tows and from horizontal net tows performed at discrete depths

relation between SST amplitude and trichome abundance (Kendall rank correlation $p>0.1$ for all running averages). Colonies appear to increase in abundance only after extended periods of water column stratification (Fig. 2A).

Single trichome concentrations follow a seasonal cycle with low densities ( $<4.0 \times 10^{4}$ trichomes $\mathrm{m}^{-3}$ ) observed during winter and spring months. Trichome abundance also displays an interannual variability with significantly higher values of single trichomes in the water column during 1991 and 1992 (Wilcoxon 2 sample test $p<0.05$; Fig. 2).

During 1991 and 1992, Trichodesmium contortum, a species not described previously for the central North Pacific Ocean and characterized by the screw-like shape of its trichomes, appeared sporadically in the net samples. Although $T$. contortum was never abundant

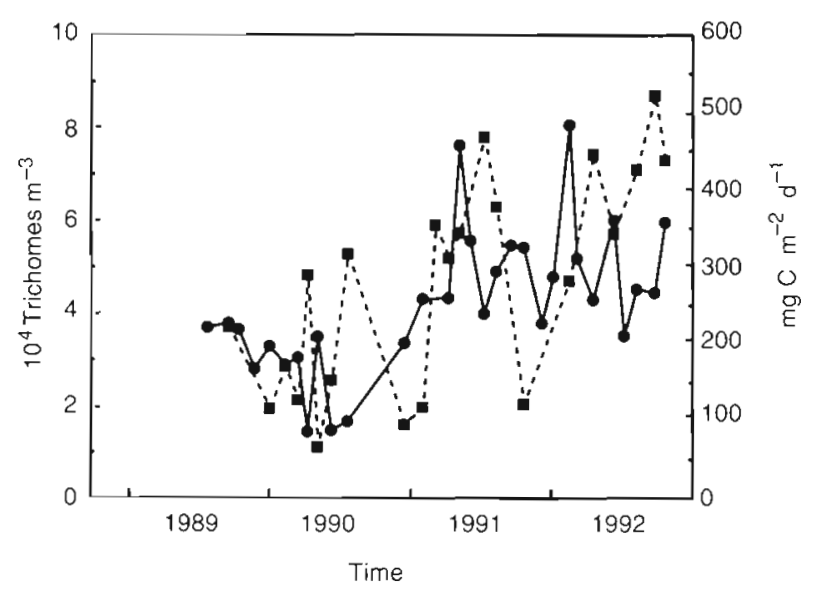

Fig. 4. Trichodesmium spp. Temporal variation of photosynthetic carbon assimilation ( $)$ integrated over the upper $45 \mathrm{~m}$ depth and average density of single trichomes ( $\boldsymbol{\square}$ ) over the same depth range
Table 1. Trichodesmium spp. Elemental composition and chlorophyll a (chl a) content of single trichomes and colonies [mean ( $(\mathrm{SD})$ ]. PC: particulate carbon; PN: particulate nitrogeni PP: particulate phosphorus

\begin{tabular}{|c|c|c|c|}
\hline \multirow[t]{2}{*}{ Parameter } & \multicolumn{2}{|c|}{ Single } & \multirow[t]{2}{*}{ Colonies" } \\
\hline & May 90 & Oct 91 & \\
\hline Chl a (ng filament ${ }^{-1}$ ) & 0.27 & 0.26 & $0.32(0.034)$ \\
\hline PC (ng filament $\left.{ }^{-1}\right)$ & 50.0 & 51.6 & $52.7(1.8)$ \\
\hline PN (ng filament ${ }^{-1}$ ) & 9.2 & 9.8 & $9.6(0.4)$ \\
\hline PP (ng filament ${ }^{-1}$ ) & 0.40 & 0.48 & $0.51(0.07)$ \\
\hline PC:chl $a(w: w)$ & 187 & 199 & $163(29.2)$ \\
\hline PC:PN (mol:mol) & 6.34 & 6.14 & $6.4(0.35)$ \\
\hline PN:PP (mol:mol) & 52 & 45 & $42\{6.15\}$ \\
\hline
\end{tabular}

in our samples $[<1 \%$ of the total Trichodesmium biomass ( $T$. thiebautii and $T$. erytheaum are the dominant species)], it was always present at one or several depths in all cruises between April 1991 and October 1992.

An increase in primary production in the upper $45 \mathrm{~m}$ of the water column was also observed during 1991 and 1992 (Karl et al. 1995; Fig. 4) suggesting that the abundance of trichomes and the amount of carbon production may be controlled by the same factors. However, short term increases in primary production appear to be correlated with decreases in the abundance of trichomes (Fig. 4).

The mean elemental composition of colonies as well as single trichomes does not vary significantly between the 2 morphologies; only the carbon to chlorophyll ratio between single trichomes and colonies varies (Table 1). The $\mathrm{C}: \mathrm{N}$ ratio was remarkably similar when comparing results from samples collected in May 1990 and October 1991. These results contrast with the observed change in the elemental composition of the bulk particulate matter in the upper $45 \mathrm{~m}$ of the water column between 1989 and 1992 (Table 2). Based on

Table 2. Elemental ratio of $01045 \mathrm{~m}$ depth integrated particulate matter at Stn ALOHA and comparison of the median elemental ratio with the theoretical Redfield ratio of $106 \mathrm{C}: 16 \mathrm{~N}: 1 \mathrm{P}$

\begin{tabular}{|lcccc|}
\hline $\begin{array}{l}\text { Elemental } \\
\text { ratio }\end{array}$ & Period & $\begin{array}{c}\text { Mean } \\
\text { (mol:mol) }\end{array}$ & $\begin{array}{c}\text { Median } \\
\text { (mol:mol) }\end{array}$ & $\begin{array}{c}\text { Significance } \\
\text { level }^{a}\end{array}$ \\
\hline PC:PN & $1989-90$ & 9.06 & 7.08 & $0.05<\mathrm{p}<0.1$ \\
& $1991-92$ & 7.22 & 6.86 & $\mathrm{p}>0.1$ \\
PC:PP & $1989-90$ & 114.1 & 113.7 & $\mathrm{p}>0.1$ \\
& $1991-92$ & 132.9 & 132.0 & $\mathrm{p}<0.001$ \\
PN:PP & $1989-90$ & 14.1 & 14.6 & $\mathrm{p}>0.1$ \\
& $1991-92$ & 19.3 & 18.2 & $\mathrm{p}<0.05$ \\
\multicolumn{5}{|l}{ a Based on Wilcoxon's ranks test } \\
\end{tabular}




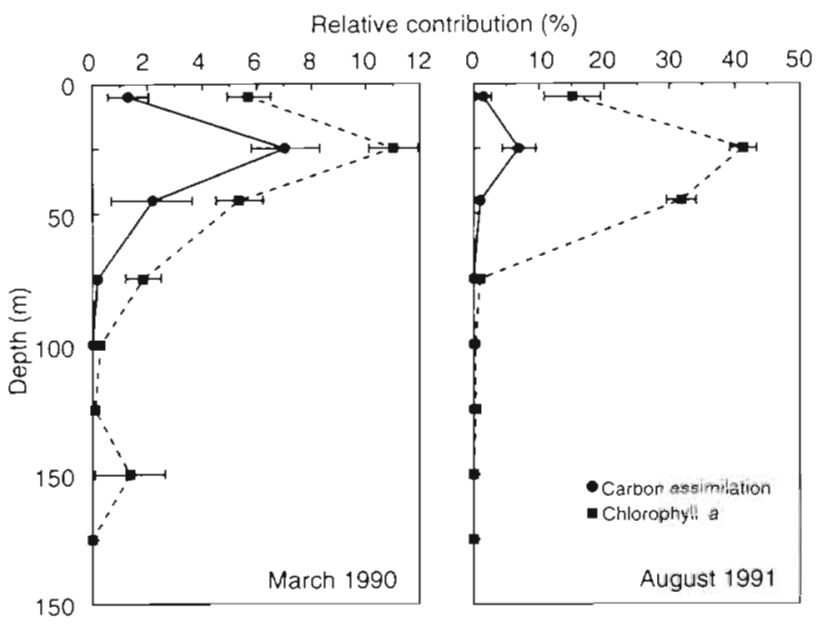

Fig. 5. Trichodesmium spp. Depth distribution of the contribution of Trichodesmium spp., as percentage, to total photosynthetic carbon assimilation ( ) and total $\mathrm{chl}$ a (

Wilcoxon's signed rank test analyses, the phosphorus content in the suspended particulate matter for the perıod 19y1-19y'2 is on average significantly lower than the Redfield ratio (Redfield et al. 1963).

Even though chl a contributed by Trichodesmium may be as high as $40 \%$ of the total chl a measured at a discrete depth (Fig. 5), integrated values from 0 to $45 \mathrm{~m}$ account for no more than $28 \%(\bar{x}=18 \%, s=8 \%, n=$ 22). Carbon assimilation contribution is always lower than the chl a contribution (Fig. 5) suggesting that the carbon assimilation efficiency of Trichodesmium is lower than the assimilation efficiency of the phytoplankton community as a whole.

\section{DISCUSSION}

The only report available on the spatial distribution of single filaments of Trichodesmium (trichomes) in the water column derives from a study in the Central and North Pacific Ocean. On a transect from $50^{\circ} \mathrm{N}$ to $10^{\circ} \mathrm{S}$ along $155^{\circ} \mathrm{W}$, Marumo \& Asaoka (1974b) found large concentrations of filaments $\left(>5 \times 10^{4}\right.$ trichomes $\mathrm{m}^{-3}$ ) restricted to the upper $50 \mathrm{~m}$ of the subtropical gyre (from $15^{\circ} \mathrm{N}$ to $29^{\circ} \mathrm{N}$ ). These concentrations are higher, but not significantly different from the average abundance of single trichomes found in the upper water column of Stn ALOHA $\left(\bar{x}=4.6 \times 10^{4}\right.$ trichomes $\mathrm{m}^{-3}$, $\mathrm{s}=2.3 \times 10^{4}$ trichomes $\mathrm{m}^{-3}, \mathrm{n}=22$ ). By comparing these concentrations with the abundance of Trichodesmium cells in the colony morphology found at Stn ALOHA, we conclude that colonies comprise a minor fraction $(12 \%)$ of the Trichodesmium population in our study.

Due to the methodologies used to collect single trichomes and colonies in the present study, the possi- bility of overestimating single trichome and underestimating colony densities as a result of the mechanical disruption of colonies exists. However, the slope of the linear regression between integrated colony concentration calculated from vertical net tows and from samples collected at discrete depths (horizontal net tows) was not different from $1.0(95 \%$ confidence limits $=$ 0.84 and 1.06, $R^{2}=0.85, n=9$; Fig. 3). Because, on average, each horizontal net tow filtered $43 \mathrm{~m}^{3}$ and vertical net tows only filtered $16 \mathrm{~m}^{3}$ this result suggests that the percentage of colonies disrupted is not a function of the volume filtered by the net. Given the average abundance of colonies estimated for the upper $50 \mathrm{~m}$ of the water column $\left(\bar{x}=31\right.$ colonies $\left.\mathrm{m}^{-3}\right)$, the complete disruption of Trichodesmium bundles would account for less than $14 \%$ of the estimated average abundance of single trichomes. Furthermore, because colonies are probably subjected to a higher stress during a net tow than during a rosette water sampling procedure, we believe that our calculations of single trichome densities are not significantly affected by colony disruption.

Carpenter \& Romans (1991) calculated from historical data that Trichodesmium colonies contribute $60 \%$ of the total chl a measured in small sample volumes (200 to $300 \mathrm{ml}$ ) collected in the upper water column of the western North Atlantic Ocean. This high contribution indicates that most of the Trichodesmium biomass in the western North Atlantic Ocean must be in the colonial morphology. Free trichomes were not enumerated in that study. A marked difference in morphological composition and in the difference of the estimated contribution of Trichodesmium to organic matter (Table 3) suggests that there may be significant ecological differences between these 2 marine environments. This conclusion precludes the possibility of freely extrapolating results from one ocean basin to another.

Although there is no significant correlation between calm weather periods, as distinguished by the diel

Table 3. Trichodesmium spp. Temporal variation in the contribution of single trichomes to total suspended particulate carbon (PC), particulate nitrogen (PN), particulate phosphorus (PP), and chlorophyll a ( $\mathrm{Chl}$ a) in the upper $45 \mathrm{~m}$ of the euphotic zone at Stn ALOHA

\begin{tabular}{|lccr|}
\hline Parameter & $\begin{array}{c}1989-1992 \\
(\%)\end{array}$ & $\begin{array}{c}1989-1990 \\
(\%)\end{array}$ & \multicolumn{1}{c|}{$\begin{array}{c}1991-1992 \\
(\%)\end{array}$} \\
\hline PC & $9.2 \pm 3.4^{\mathrm{d}}$ & $5.8 \pm 2.7$ & $11.3 \pm 3.3$ \\
PN & $10.8 \pm 4.5$ & $7.2 \pm 2.9$ & $13.3 \pm 3.7$ \\
PP & $4.6 \pm 2.4$ & $2.2 \pm 1.1$ & $5.3 \pm 1.9$ \\
Chl a & $13.4 \pm 8.1$ & $8.1 \pm 6.4$ & $17.1 \pm 7.0$ \\
Mean \pm 1 SD of the mean & & \\
\hline
\end{tabular}


amplitude of the SST at $23^{\circ} 24^{\prime} \mathrm{N}, 162^{\circ} 18^{\prime} \mathrm{W}$, and the abundance of single trichomes in the upper $45 \mathrm{~m}$ of the euphotic zone at Stn ALOHA, low Trichodesmium densities appear consistently during deep mixing events and winter months. Nevertheless, low concentrations observed during May to June 1990 and October 1991 do not appear to be the result of deep mixing events. These observations suggest that environmental factors other than wind driven events and sea surface temperatures, perhaps cloud cover, solar irradiance and grazing pressure, may play an important role in controlling Trichodesmium distribution and abundance on short time scales (days).

On larger time scales, the interannual variability in Trichodesmium abundance observed in the upper $45 \mathrm{~m}$ of the water column during 1991 to 1992 may be the result of a decrease in the frequency of deep mixing events (Karl et al. 1995). Extended periods with a shallow mixed-layer will benefit phytoplankton such as Trichodesmium that have the capacity to regulate their buoyancy (Fogg 1982, Komopka 1984, Karl et al. 1992).

The elemental composition of Trichodesmium is surprisingly constant when comparing single trichomes and colonies (Table 1). The PC:PN molar ratio (6.3:1) is close to the predicted Redfield ratio $(6.6: 1)$ but the PN:PP (45:1) is 3 times greater than Redfield stoichiometry $(16: 1)$. These results are consistent with observations reported in previous studies (Mague et al. 1977, McCarthy \& Carpenter 1979, Lewis et al. 1988, Karl et al. 1992, 1995). A low phosphorus cell quota appears as a characteristic of Trichodesmium cells whether in free trichome or colony morphology. Furthermore, the chemical analysis of actively photosynthetic colonies collected during a bloom event in the vicinity of Stn ALOHA yielded a PN:PP ratio of 125:1 (Karl et al. 1992), suggesting a large flexibility in the cell quota phosphorus in Trichodesmium.

The contribution to the integrated photosynthetic carbon assimilation by Trichodesmium during March 1990 and May 1991 in the upper $45 \mathrm{~m}$ of the water column at Stn ALOHA was estimated to be 3.9 and $4.3 \%$ of the total production, respectively (Fig. 5). Although the primary production below $45 \mathrm{~m}$ accounted for 65 and $43 \%$ of the 0 to $200 \mathrm{~m}$ integrated production, the contribution by Trichodesmium was negligible below $75 \mathrm{~m}$. Based on these results, the estimated contribution of Trichodesmium to total inorganic carbon assimilation was approximately $1.7 \%$ during March 1990 and $2.5 \%$ during August 1991

The fraction of autotrophic production attributed to Trichodesmium does not appear to be important unless we consider this contribution in terms of new production. Based on the downward flux of PN measured at Stn ALOHA and assuming that photoautotrophic pro- duction of particulate matter is close to C:N Redfield ratio, the estimates of particulate exported production at $150 \mathrm{~m}$ [downward particulate flux $\times$ (total production $)^{-1}$ ] range from 0.02 to 0.12 between 1989 and 1992 $(\overline{\mathrm{X}}=0.06, \mathrm{~s}=0.02, \mathrm{n}=39)$.

Field incubations (Mague et al. 1977), as well as the nitrogen isotopic signature of Trichodesmium $\left(\delta^{15} \mathrm{~N}=\right.$ -1.7 to +0.5 ppm; Wada \& Hattori 1976) indicate that nitrogen fixation accounts for virtually all cellular nitrogen required for this organism to grow. Because the N:C ratio observed for Trichodesmium is not significantly different from the Redfield ratio, we can use carbon assimilation as an estimate of nitrogen fixation. If the values of carbon assimilated by Trichodesmium measured during March 1990 and August 1991 are representative of its contribution to production at Stn ALOHA, then Trichodesmium accounts, on average, for $27 \%$ of new production (21\% during 1989 to 1990 and $35 \%$ during 1991 to 1992 j. However, this estimate should be viewed as a lower boundary value because it does not take into account either bloom events (Karl et al. 1992) or the potential release of $\mathrm{NH}^{+}{ }_{4}$ and dissolved organic nitrogen (DON) by Trichodesmium during nitrogen fixation (see below).

The highest carbon assimilation observed in the first $4 \mathrm{yr}$ of the HOT program occurred during August 1989. Although an increase in the abundance of Trichodesmium was observed at the time of this primary productivity experiment, a large bloom did occur 3 d later at Stn ALOHA (Karl et al. 1992). This observation suggests that trichomes were already abundant at the time of the incubations. However, there is no evidence of an increase in phytoplankton biomass when comparing the concentration of chl a measured from the primary productivity cast with values obtained in either previous or subsequent months (Fig. 6A). The only strong evidence suggesting that a change occurred in the water column was found in the carbon assimilation efficiency of the phytoplankton $\left(\mathrm{P}^{\mathrm{B}}\right)$ and the $\mathrm{C}: \mathrm{N}$ ratio of particulate matter. The carbon assimilation efficiency increased by a factor of 2 in the upper $50 \mathrm{~m}$ the water column (Fig. 6B) while the $C: N$ ratio decreased from 7.3:1 to $6.3: 1$ (mol:mol; Fig. 6C). Assuming that the Redfield ratio for phytoplankton is $6.6: 1$, the shift in the particulate elemental ratio suggests that phytoplankton were not nitrogen limited during August 1989.

Trichodesmium carbon assimilation number $\left(\mathrm{P}^{B}\right)$ reported in the literature and calculated for Stn ALOHA over the period of this study are relatively low, ranging from 0.17 to $3.8 \mathrm{~g} \mathrm{C}(\mathrm{g} \mathrm{chl} \mathrm{a})^{-1} \mathrm{~h}^{-1}$ (Carpenter \& Price 1977. Mague et al. 1977, Lewis et al. 1988, Karl et al. 1992; Fig. 7). Hence, the increase in $\mathrm{P}^{\mathrm{B}}$ observed in August 1989 and during 1991-1992 cannot be explained by an increase of the contribution of Trichodesmium to the total production in the euphotic zone 

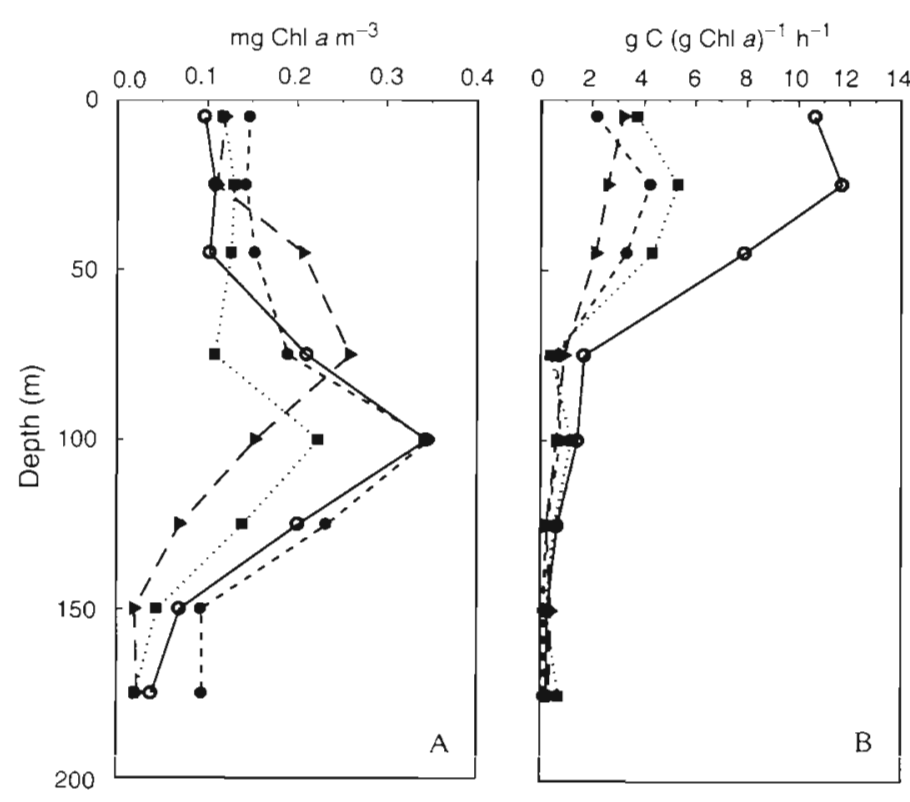

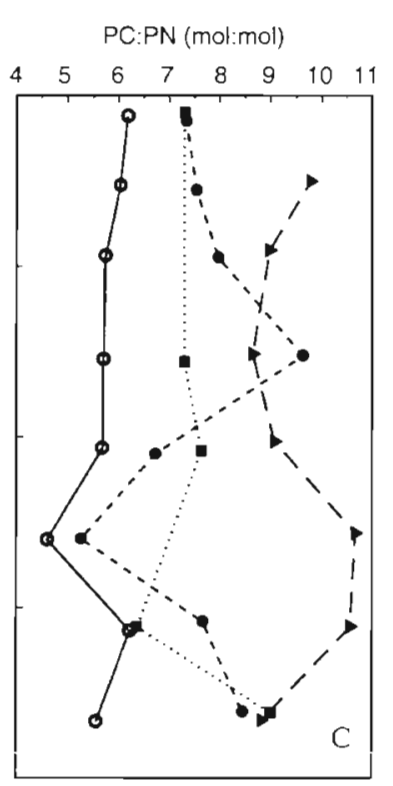

Fig. 6. Depth profiles of (A) chl a concentrations, (B) phytoplankton assimilation efficiency, and (C) molar ratio of carbon to nitrogen in the suspended particulate matter measured in samples collected at Stn ALOHA between July and November 1989. (•) July; (O) August; (-) Septemberi(4) November samples
However, 2 lines of evidence suggest the existence of a synergistlc efiect between Trichodesmium and other algae present in the water column. The first observation is derived from the primary productivity experiments performed during March 1990 and August 1991 (Fig. 7). In both cases the incubations at 25 and $45 \mathrm{~m}$ showed that the $\mathrm{P}^{\mathrm{B}}$ of samples containing 1 colony was higher than the calculated $P^{B}$ based on results from the independent incubation of colonies and phytoplankton. This effect was not evident at $5 \mathrm{~m}$ depth and may have been inhibited by high light conditions (Li et al. 1980, Lewis et al. 1988).

If we consider the supply of nitrogen to be limiting the algal production in the upper euphotic zone it is possible to speculate that a release of $\mathrm{NH}_{4}{ }^{+}$and dissolved organic matter rich in DON during nitrogen fixation (Prufert-Bebout et al. 1993, Glibert \& Bronk 1994) will enhance the production of phytoplankton other than Trichodesmium. Under high irradiance (the $5 \mathrm{~m}$ depth sample) the production of oxygen due to photosynthesis could be inhibiting nitrogenase activity thus suppressing nitrogen fixation. Trichodesmium colonies have high respiration rates (Kana 1992), and the light intensity of the compensation point for oxygen evolution in these colonies is approximately $300 \mu \mathrm{E} \mathrm{m}{ }^{2} \mathrm{~s}^{1}$ (or $13 \mathrm{E} \mathrm{m}^{-2} \mathrm{~d}^{-1}$ ) corresponding to the irradiance measured at $30 \mathrm{~m}$ depth at Stn ALOHA. One of the metabolic benefits of a high respiration rate is the protection of nitrogenase activity by reducing the intracellular oxygen tension during daylight hours. From this perspec-

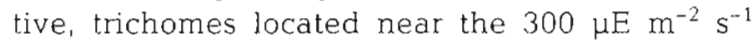
isolume may have higher nitrogenase activity than those located closer to the sea surface
Nevertheless, we need to be careful with the interpretation of nistoricai vaiues of $\hat{\mathrm{P}}^{\mathrm{B}}$ given for Trichodesmium, and with the results of the experiment discussed above. Assimilation numbers in Trichodesmium have been calculated only by using colonial morphologies where trichomes are subject to self shading effects. In the samples collected during this study, only chl a concentration per unit biomass (PC) increases in colonies when compared to single trichomes (Table 1). Although the increase in this ratio is not significant due to the variability associated with measurement in colonies, it suggests that some degree of photoadapta-

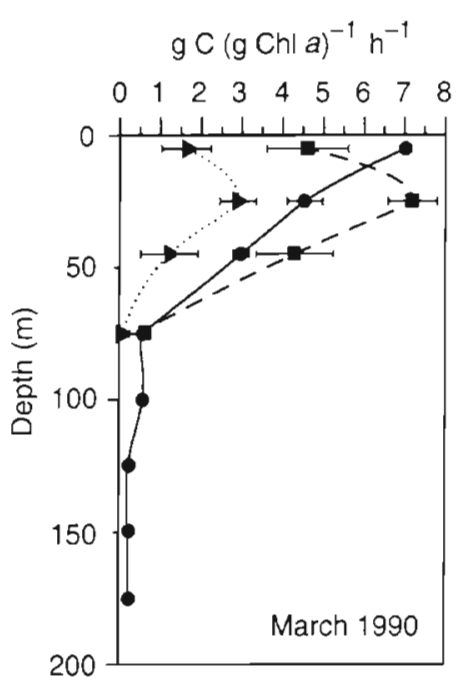

$\mathrm{g} C(\mathrm{~g} \mathrm{Chl} \mathrm{a})^{-1} \mathrm{~h}^{-1}$
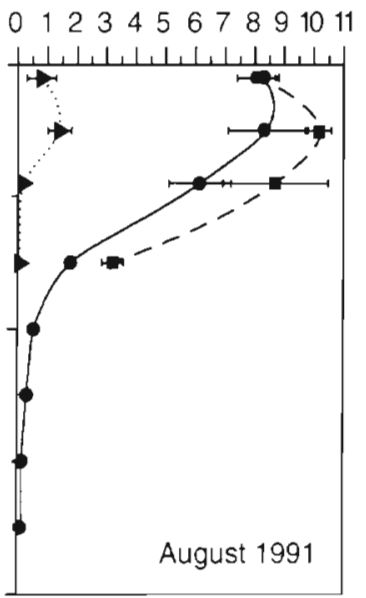

Fig. 7. Trichodesmium spp. Depth distribution of assimilation eff 1 ciency measured simultaneously in colonies (4), natural phytoplankton assemblages $(\bullet)$, and natural phytoplankton assemblages amended with colonies ( $\mathbf{})$. Error bars represent standard deviations 
tion may occur in colonies as a result of self shading. This observation is also consistent with the decrease in PC:chl a observed during bloom conditions (Karl et al. 1992). However, the relative decrease in PC:chl $a$ in colonies found under non-bloom conditions during this study suggests that photoadaptation between different morphologies is not strong and may account for no more than a $20 \%$ increase of $\mathrm{P}^{\mathrm{B}}$ between colonies and single trichomes (Table 1).

The possibility that handling the colonies in the preparation of primary production experiments may have disrupted microenvironments (Carpenter \& Price 1976, Martinez et al. 1983) and damaged trichomes cannot be excluded (but see Carpenter et al. 1987 and Scranton et al. 1987). Although colonies inspected under a microscope before the inoculations did not appear broken, $20 \%$ of the incubation bottles at the end of the incubation period had some single trichomes. If damage occurred in the colonies the low $\mathrm{P}^{\mathrm{B}}$ value calculated for colonies must be considered an artifact of the experimental manipulations.

A second line of evidence suggesting that Trichodesmium is a source of nitrogen for other phytoplankters comes from the observed shift in elemental ratio of the particulate matter and its correlation with the abundance of trichomes in the upper $45 \mathrm{~m}$ of the water column (Fig. 8). Sixty percent of the variability in PN:PP may be attributed to variations in the abundance of Trichodesmium. Nevertheless, an increase in the percentage contribution of Trichodesmium biomass to the total suspended particulate matter is not sufficient to explain the change in the elemental ratio of the suspended particulate matter (Table 2).

By knowing the approximate contribution of carbon, nitrogen, and phosphorus in Trichodesmium (Table 3), it is possible to calculate the elemental composition of

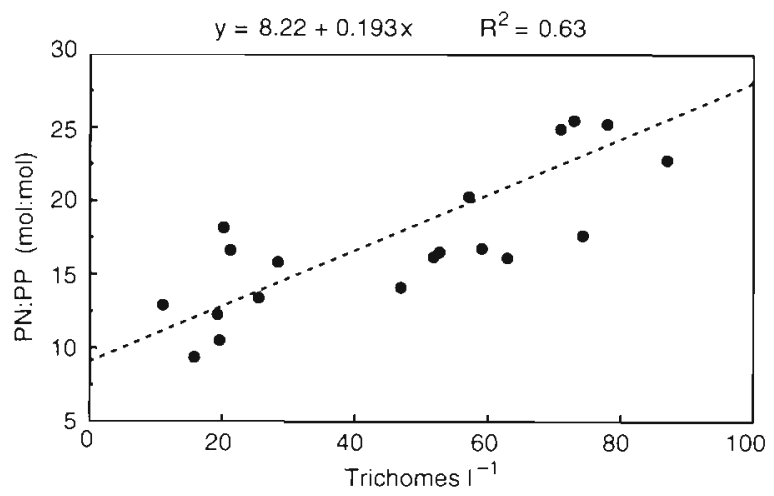

Fig. 8. Trichodesmium spp. Molar ratio of 0 to $45 \mathrm{~m}$ depth integrated nitrogen (PN) to phosphorus (PP) concentration in suspended matter plotted against the average concentration of single trichomes over the same depth range. A model II geometric mean linear regression was used to model the relation between both parameters
Table 4. Temporal variation in the elemental ratio of suspended particulate matter after removing the contribution of single trichomes in the upper $45 \mathrm{~m}$ of the euphotic zone at Stn ALOHA

\begin{tabular}{|lccc|}
$\begin{array}{l}\text { Elemental } \\
\text { ratio }\end{array}$ & $\begin{array}{c}1989-1992 \\
\text { (mol:mol) }\end{array}$ & $\begin{array}{c}1989-1990 \\
(\mathrm{~mol}: \mathrm{mol})\end{array}$ & $\begin{array}{c}1991-1992 \\
\text { (mol:mol) }\end{array}$ \\
\hline PC:PN & 7.7 & 8.0 & 7.3 \\
PN:PP & 15.3 & 13.5 & 16.6 \\
\hline
\end{tabular}

the remaining bulk particulate matter. This residual PN:PP of the particulate organic matter in the upper $45 \mathrm{~m}$ of the water column, excluding Trichodesmium, varies from 13.5:1 (mol:mol) in 1989-1990 to 16.6:1 (mol:mol) in 1991-1992 (Table 4) suggesting that nitrogen is not a limiting nutrient during the latter period of the present study.

Two different processes related to the presence of Trichodesmium may be taking place in the euphotic zone. The first, discussed above, is the release of $\mathrm{NH}_{4}{ }^{+}$ and DON during the process of nitrogen fixation. The second process is the release of other essential nutrients during the senescence of trichomes. Evidence in the literature indicates that Trichodesmium degrades very fast (hours to days) upon reaching senescence (Van Baalen \& Brown 1969, Borstad \& Borstad 1984). If this is the case at Stn ALOHA, a decrease in the concentration of trichomes between cruises could result in the release of nutrients, such as phosphorous, to other phytoplankton taxa. This interpretation is consistent with the observed trend of photosynthetic carbon assimilation and Trichodesmium densities at Stn ALOHA. The increase in abundance of trichomes in the upper water column during 1991 to 1992 coincides with an increase of photosynthetic carbon assimilation although, on smaller temporal scales (weeks to month), primary production appears to be inversely correlated to Trichodesmium abundances (Fig. 4). The increase in carbon assimilation rates, following a decrease in trichome abundance between cruises, may indicate that the release of nutrients as a result of Trichodesmium senescence is an important ecological process, even under non-bloom conditions.

Karl et al. (1995) have suggested that the biogeochemical shift observed between 1989 to 1990 and 1991 to 1992 may be a result of an increase of the stratification in the water column during an El NiñoSouthern Oscillation (ENSO) event. If the coupling between Trichodesmium abundance, water column stratification, and ENSO periods proves to be correct, we should expect to observe a relaxation of nitrogen deficiency of the pelagic ecosystem of the North Pacific subtropical gyre during ENSO events. This relaxation would result from the combined effect of the reduction 
of nutrient inputs due to deep mixing events and the increase of nitrogen fixation by Trichodesmium and other diazotrophs

In conclusion, the observed change in PN:PP in the upper $45 \mathrm{~m}$ of the water column at Stn ALOHA appears to be the result of a decrease in the frequency of deep mixing events. Because of the capacity to regulate its buoyancy to fix $\mathrm{N}_{2}$. Trichodesmium may play a significant role in the input of nutrients when the euphotic zone water column is stratified for extended periods of time. Furthermore, an over production of reduced nitrogen and the concomitant extracellular release of ammonium and DON by Trichodesmium may explain the relative enrichment in PN observed at Stn ALOHA during 1991 and 1992.

Perhaps because the focus of research on oceanic photoautotrophic production was historically influenced by problems related to the management of fisheries (Ryther 1969), the contribution of nitrogen fixation to total production estimated for the North Pacific subtropical gyre may have been considered of little importance. However, the contemporaneous concepts of new production and exported biogenic maliet from the euphotic zone have become central in the analysis of biogeochemical cycles in the ocean during the past decade (Longhurst 1991). This is the result of our interest and necessity to estimate the role of the oceans in global carbon cycles. In this context, results obtained during the first $4 \mathrm{yr}$ of the HOT-series program suggest that the contribution of nitrogen fixation by Trichodesmium in the North Pacific subtropical gyre may provide a significant fraction of the nitrogen supporting new production.

Acknowledgements. We thank the captains, crews and scientists participating in the HOT program for assistance in the collection and analysis of samples. We also thank Roger Lukas and the HOT-WOCE team for the generation of hydrographic data, the National Oceanic and Atmospheric Administration-National Data Buoy Center (NOAA-NDBC) for access to the ocean data recorded by buoy $\# 51001$, and $E$. $J$. Carpenter and 2 anonymous reviewer for helpful comments and suggestions. The present study was supported by National Science Foundation grants OCE 88-00329, OCE 90-16090, and OCE 93-01368 (awarded to D.K.), and OCE 87-17195 and OCE 93-03094 (awarded to R. Lukas). SOEST publication no. 3937 .

\section{LITERATURE CITED}

Bergman B, Carpenter E.J (1991) Nitrogenase confined to randomly distributed trichomes in the marine cyanobacterium Trichodesmium thiebautii. J Phycol 27:158-165

Bjornberg TKS (1965) Observations on the development and the biology of the Miracidae Dana (Copepoda: Crustacea). Bull mar Sci 15:512-520

Borstad GA, Borstad LE (1977) The Oscillatona erythreae (Cyanophyta) community of associates. In: Steward HB (ed) Cooperative investigations of the Carrbbean and adjacent regions. FAO, Rome, p 51-57

Borstad GA, Borstad L.E (1984) Needle-like projectiles observed issuing from lysing Trichodesmium (Cyanophyta) cells. Limnol Oceanogr 29:1097-1099

Borstad GA, Brinckmann-Voss A (1979) On Pelaglana trichodesmiae n. gen., family Pandeidae, (Anthomedusae/Athecatae, Cnidarial, a new hydrozoan associated with the planktonic cyanophyte Trichodesmium thiebautii. Can J Zool 57:1232-1237

Bowman TE, Lancaster LJ (1965) A bloom of the planktonıc blue-green alga Trichodesmium erythraeum in the Tonga Islands. Limnol Oceanogr 10:291-293

Bryceson I, Fay P (1981) Nitrogen fixation in Oscillatoria (Trichodesmium) erythraea in relation to bundle formation and trichome differentiation. Mar Biol 16:159-166

Calef GW, Grice GD (1966) Relationship between the bluegreen alga Trichodesmium thiebautii and the copepod Macrosetella gracilis in the plankton off north-eastern. South America. Ecology 47:855-856

Capone DG, Ferrier MD, Carpenter EJ (1994) Amino acid cycling in colonies of the planktonic marine cyanobactenum Trichodesmium intebautii. Appl environ Microbiol 60:3989-3995

Capone DG, O'Neil JM, Zehr J, Carpenter EJ (1990) Basis for diel variation in nitrogenase activity in the marine planktonic cyanobacterium Thchodesmium thiebautii. Appl environ ivíiciuluiou $50.3532-3536$

Capone DG, Reuter JR, Carpenter EJ (1992) Overview of the advanced research workshop on bloom-forming marine cyanobacteria. In: Carpenter EJ, Capone DG, Reuter JG (eds) Manne pelagıc cyanobacteria: Trichodesmium and other diazotrophs. Kluwer Academic Publishers, Boston, p $1-8$

Carpenter EJ (1983) Physiology and ecology of the marine plankton Oscillatoria (Trichodesmium). Mar Biol Lett 4 . $69-85$

Carpenter EJ, Chang J, Cottrell M, Schubauer J, Paerl HW, Bebout BM, Capone DG (1990) Re-evaluation of nitrogenase oxygen-protective mechanisms in the planktonic manne cyanobacterium Trichodesmium. Mar Ecol Prog Ser 65:151-158

Carpenter EJ, Price CC IV (1976) Marine Oscillatoria (Trichodesmium): explanation for aerobic nitrogen fixation without heterocysts. Science 191:1278-1280

Carpenter EJ, Price CC IV (1977) Vitrogen fixatton, distribution and production of Oscillatoria (Trichodesmium) thiebautii in the eastern Sargasso Sea. Limnol Oceanogr 20: $381-401$

Carpenter EJ, Romans K (1991) Major role of the cyanobacterium Trichodesmium in nutrient cycling in the North Atlantic Ocean. Science 254:1356-1358

Carpenter EJ, Scranton MI, Novelli PC, Michaels A (1987) Validity of $\mathrm{N}_{2}$ fixation rate measurements in marine Oscillatoria (Trichodesmium). J Plankton Res 9:1047-1056

Codispoti LA (1989) Phosphorus vs nitrogen Limitation of new and exported production. In: Berger $\mathrm{H}$, Smetacek VS, Wefer $G$ (eds) Life sciences report, 44: productivity of the ocean: past and present. Dahlem Workshop Reports, J Wiley \& Sons. Chichester, p 377-394

Devassy VP, Bhattathiri PMA, Quasim SZ (1978) Trichodesmium phenomenon. Indian J mar Sci 7:168-186

Devassy VP, Bhattathri PMA, Quasim SZ (1979) Succession. of organisms following Trichodesmium phenomenon. Indian $J$ mar Sci 8:89-93

Dupuoy C, Petit M, Dandonneau Y (1988) Satellite detected cyanobacteria bloom in the southwestern tropical Pa- 
cific: Implication for ocuenographic nitrogen fixation. Int J Remote Sens 9:389-396

Fogg GE (1982) Nitrogen cycling in sea waters. Phil Trans R Soc Lond B269:511-520

Geiselman JA (1977) Marine colonial hydroid inclusion discovered within Oscillatorla colonies. Bull mar Scl 27 $821-824$

Glibert PM, Bronk DA (1994) Realcase of (issolved nitrogen by marine diazotrophic cyanobacteria, Trichodesmium spp. Appl environ Microbiol 60:3996 4000

Kana TM (1992) Oxygen cycling in cyanobacterla with specific reference to oxygen protection in Trichodesmium spp. In: Carpenter EJ, Capone DG, Reuter JG (eds) Marine pelagic cyanobacteria: Trichodesmum and other diazotrophs. Kluwer Academic Publishers, Boston, p 29-41

Karl DM, Letelier R, Hebel DV, Bird DF, Winn CD (1992) Trichodesmium blooms and new nitrogen in the North Pacific gyre. In: Carpenter EJ, Capone DG, Reuter JG (eds) Marine pelaglc cyanobacteria: Trichodesmium and other diazotrophs. Kluwer Academic Publishers, Boston, p 219-237

Karl DM, Letelier R, Hebel DV, Tupas T, Dore J, Chrıstian J, Winn C (1995) Ecosystem changes in the North Pacific subtropical gyre attributed to the 1991-1992 El Niño. Nature 373:230-234

Karl DM, Lukas R (in press) The Hawaii Ocean Time-series (HOT) program: background, rationale and field implementation. Deup sea Res

Karl DM, Winn CD (1991) A sea of change: monitoring the oceans' curbon cycle. Environ Sci Technol 25:1976-1981

Komopka A (1984) Effect of light-nutrient interactions upon physiological state of planktonic cyanobacteria. In: Kinq MI, Reddy C (eds) Current perspectives in microbial ecology. American Society of Microbiology, Washington, DC, p 41-48

Letelier RM, Bidıgare RR, Hebel DV, Ondrusek M, Winn CD, Karl DM (1993) Temporal variability of phytoplankton community structure based on pigment analysis. Limnol Oceanogr 38:1420-1437

Letelier RM, Dore JE, Winn CD. Karl DM (in press) Temporal variations in photosynthetic carbon assimilation efficiencles at Stra ALOHA. Deep Sea Res

Lewis MR, Ulloa O, Platt T (1988) Photosynthetic action, absorption, and quantum yield spectra for natural population of Oscillatoria in the North Atlantic. Limnol Oceanogr 33:92-98

Li WKW, Glover HE, Morris I (1980) Physiology of carbon photoassimilation by Oscillatoria thiebauttii in the Caribbean Sea. Limnol Oceanogr 25:447-456

Longhurst AR (1991) Role of the marine biosphere in the global carbon cycle. Limnol Oceanogr 36:1507-1526

Mague TH, Mague FC, Holm-Hansen O (1977) Physiology and chemical composition of nitrogen fixing phytoplankton in the central North Pacific Ocean. Mar Biol 41:75-82

Martinez L, Sulver MW, King JM, Alldredge AL (1983) Nitrogen fixation in floating diatom mats: a source of new nitrogen to olngotrophic ocean waters. Science 221:152-154

Marumo R, Asaoka O $(19 ; 4$ a) Trichodesmum in the East China Sea. 1 Distribution of Trichodesmium thiebautii Gomont during 1961-1967. J Oceanogr Soc Japan 30:48-53

Marumo R, Asaoka O (197.4b) Distribution of pelagic blue-
This article was presented by B. and E. Sherr (Senior

Editorial Advisors), Corvallis, Oregon, LS.1 green algae in the North Pacific Ocean. J Oceanogr Soc Japan 30:77-85

Marumo R, Nagasawa S (1976) Seasonal variation of the standing crop of the pelagic blue-green alga, Trichodesmium in the Kuroshio water Bull Plankton soc Japan 23 $19-25$

McCarthy JJ, Carpenter EJ (1979) Oscillatoria (Trichodesmilm) threbautii (Cyanophyta) in the central North Atlantic Ocean. J Phycol 15:75-82

Ohki K, Fujita Y (1988) Aerobic ntrogenase activity measured as acetylene reduction in the marine non-heterocystous cyanobacterium Trichodesnium spp. grown under artifi. cial conditions. Mar Biol 98:111-114

Omori M (1965) A 160-cm opening-closing plankton net. 1 Description of the gear. J Oceanogr soc Japan 21:20-28

Paerl HW, Bebout BM (1988) Microelectrode determination of $\mathrm{O}_{2}$-depleted microzones in marine Oscillatoria spp. (Trichodesmium): a mechanism promoting contemporaneous $\mathrm{N}_{2}$ fixation and oxygenic photosynthesis. Sclence 241:442-445

Paerl HW, Bebout BM, Purfert LE (1989) Bacterial associations with marine Oscillatoria sp. (Trichodesmium sp.) populations: ecophysiological implications. J Phycol 25 $773-784$

Paerl HW, Bland PT (1982) Localized tetrazolium reduction in relation to $\mathrm{N}_{2}$ fixation, $\mathrm{CO}_{2}$ fixation, and $\mathrm{H}_{2}$ uptake in aquatic filamentous cyanobacteria. Appl environ Microbiol 43:218-226

Paerl HW, Prufert LE (1987) Oxygen-poor microzones as potential sites of microbial $\mathrm{N}_{2}$ fixation in nitrogen depleted aerobic marine waters. Appl environ Microbiol 53:1078-1087

Prufert-Bebout L, Paerl HW, Lassen C (1993) Growth, nitrogen fixation, and spectral attenuation in cultivated Trichodesmum species. Appl environ Microbiol 59:1367-1375

Redfield AC, Ketchum BH, Richards FA (1963) The influence of organisms on the composition of sea water. In: Hill NM (ed) The sea, vol. 2. Interscience, New York, p 26-77

Roman MR (1978) Ingestion of the blue-green alga Trichodesmum by the harpacticoid copepod, Macrosetella gracilis. Limnol Oceanogr 23:1245-1248

Ryther JH (1969) Photosynthesis and fish production in the sea. Science 166:72-76

Saino T, Hattori A (1982) Aerobic nitrogen fixation by the marine non-heterocystous cyanobacterium Tnchodesmium (Oscillatoria) spp.: uts protective mechanism against oxygen. Mar Biol 70:251-254

Scranton MI, Novelli PC, Michaels A, Horrigan SG, Carpenter JE (1987) Hydrogen production and nitrogen fixation by Oscillatoria thiebautil during in situ incubations. Limnol Oceanogr 32:998-1006

Steven DM, Glombitza R (1972) Oscillatory variation of phytoplankton population in a tropical ocean. Nature 237 105-107

Strickland JDH, Parsons TR (1972) A practical handbook of seawater analysis. Fish Res Bd Can 167:1-310

Van Baalen C, Brown RM (1969) The ultrastructure of the marine blue-green alga Trichodesmium erythraeum, with special reference to the cell wall, gas vacuoles, and cylindrical bodies. Arch Mikrobiol 69:79-91

Wada E, Hattori A (1976) Natural abundance of ${ }^{15} \mathrm{~N}$ in particulate organic matter in the North Pacific Ocean. Geochim Cosmochim Acta 40:249-251

Manuscript first received: March 8, 1995

Revised version accepted: September 27, 1995 